\title{
Proverbs and naturalness in mother-tongue translation: the Dagaare New Testament in perspective
}

\author{
Solomon Ali Dansieh \\ Senior Lecturer \\ Department of General and Liberal Studies \\ Wa Polytechnic, Wa, Ghana \\ Email: sdansieh@yahoo.com; sdansieh@wapoly.edu.gh
}

\section{Submitted: May 16, 2018 / Accepted: December 13, 2018 / Published: October 4, 2019}

\begin{abstract}
This paper argues that the use of proverbs in translating the Bible into mother-tongues constitutes an essential ingredient to naturalness in the receptor-language text, thereby enhancing acceptability. Thus, the subject of translating proverbs and translating using proverbs should be handled with the attention it deserves. Using the Dagaare New Testaments as the main texts, the study aims to explore the use of proverbs in the Dagaare text in general; examine how English proverbs were translated; identify which proverbs translate well between English and Dagaare; find out how parallel proverbs were used in Dagaare and how non-proverbial expressions were translated as proverbs in the RL. This study also considered how proverbs were translated as ordinary expressions and how connotative proverbs used in the Dagaare text manifest themselves. Proverbs thus identified were read out to users of the text drawn from different denominations in the area to test for naturalness. The study found that majority (50\%) of the SL proverbs translated into Dagaare were 'near natural'; $33 \%$ 'natural', and the remaining $17 \%$ 'less natural'. This study recommends that, in future reviews of the two Dagaare NT texts, translators and consultants take note of suggestions made so that proverbs/idioms and cultural equivalents that translate more naturally into the language are adopted to enhance the quality of the translation.
\end{abstract}

Keywords: Proverbs; naturalness; translation/translating; receptor language; connotativeness 


\section{Introduction}

Naturalness, accuracy and clarity in the receptor language (RL) text constitute the three cardinal principles that are often taken into account when assessing the quality of Bible translation. Anderson (1998) proposes a fourth criterion - "the criterion of perceived authenticity". For a translated text to pass the test of acceptability, it is expected to possess all the above qualities. Though these principles will be discussed in turns later under the literature review section, the main focus of this paper is on the principle of naturalness and how well this principle has been employed in translating English proverbs into Dagaare from a native speaker's point of view.

The lack of naturalness in a translation can impact negatively on the whole translation project. The target community may even reject the project on account of difficulties they may encounter in reading and understanding it. The most precarious situation is where rather than reject it outright, the text is maintained but misread and consequently, misinterpreted. Considering the importance of Bible translation, firstly as a result of its uniqueness as a book of God's own word, and secondly because of the huge financial and human capital that go into it, it is crucial that any facet of the discourse that can compromise its quality be treated with optimum diligence. Whether they are in English or Dagaare, proverbs occupy a unique place in everyday discourse. This study investigates the criterion of naturalness in the use of proverbs translated from the English source texts (NRSV, 1999) and English Standard Version (ESV, 2001) into the Dagaare New Testament as receptor language (RL) text.

\section{The Dagaaba}

The Dagaaba (Singular: Dagao), a people known to hold their culture in high esteem, are found mainly in the Upper-West Region of Ghana and parts of neighbouring Burkina Faso and La Cote d'Ivoire. Their language is known as Dagaare or Dagara, a Gur language belonging in the Niger-Congo family. The term Dagaare may also mean the culture of the people. Thus, depending on the context, if one is told that one does not know Dagaare, it could be understood as not knowing the culture of the Dagaaba or not knowing the language. Majority of the people are subsistence farmers engaged in the cultivation of food crops such as sorghum, millet, maize, groundnuts, tigernuts, cowpea and yam. In recent times the cultivation of 
non-traditional cash crops like cashew and soya is becoming popular. The cotton industry which used to be vibrant in the area during the early ' 80 s and ' 90 s is now on the verge of collapse. The people are also engaged in animal husbandry and small-scale fresh-water fishing, especially in communities along the banks of the Black Volta. The dominant religions among the Dagaaba are Christianity, Traditional African Religion and Islam.

\section{The place of proverbs in Dagaare culture}

Like in most African languages, proverbs play a very significant role in Dagaare. Proverbs abound in everyday speech among the Dagaaba: They are used in the traditional courts, in songs and dirges, and in folklore. In everyday interactions among the people, the rich use of proverbs is easily observable. On moonlit nights, it is not uncommon to hear adults, and sometimes children, trying to outdo one another in the display of skills in proverb and riddle interpretation. This is confirmed by Yankah's observation that "children in Africa sometimes engage in a game of proverbs in which participants take turns in uttering proverbs" (Yankah, 1982). With the recent proliferation of FM radio stations in Ghana, the game of proverbs has been taken to the airwaves, with both adults and children taking part in the game. Among the Dagaaba, oftentimes, the seriousness of a subject under discussion can be determined by the frequency in proverb usage in a particular communicative situation. Persons who are conversant with the proper use of proverbs and their relevant interpretations are accorded great respect. In Dagaare culture, a speaker's ability to aptly use proverbs in both formal and informal contexts is considered a mark of maturity and their linguistic prowess in the language and often received with admiration. One who is unable to understand the meaning of proverbs used in various contexts is branded "childish" and "naïve". When the wise intend to confound the unwise, they often use proverbs; hence, in Dagaare proverbs are "thrown" (loo) and not "said." When one uses a proverb in a discourse, it is literally expressed as 'throwing a proverb' (los lugo/sokpare). This assertion is affirmed by a popular proverb in Dagaare that says: Bambugo zuy bay losra lugo, meaning: "Proverbs are employed because of the unwise." When elders gather to discuss serious business, their discourse is dominated by the use of proverbs; when the sages meet, proverb use assumes centre-stage in their discourse. Considering how popular and pervasive proverb use is among 
Dansieh, S.A./Legon Journal of the Humanities Vol. 30.1 (2019)

the Dagaaba, it is only proper that the translation of a culturally-significant book like the Bible into that language takes into account the proper use and interpretation of proverbs to ensure naturalness, hence this study.

\section{Donor and receptor language tools used in this study}

In this study, Dagaare is the receptor language (RL) with English as the donor language (DL). Two versions of the New Testament in Dagaare, namely Naaymen Nopaalaa Gane, published by the Bible Society of Ghana in 2014 and the Naaymen Nolay Paalaa published by Bibles International (BI, USA) in 2015 respectively were used in this study. Proverbs cited in this study were randomly selected from the two versions. The English text that served as source text for the former was the New Revised Standard Version (NRSV, 1999).The translators explained that their choice of the NRSV was because they considered it a near-literal translation of the original Greek and Hebrew texts, thus making it closer to the original. The NRSV has also received wide acclaim and broad support from academics and church leaders as "a bible for all Christians" (www.biblestudytools.com ). The English Standard Version (ESV, 2001) served as source text for the latter. Translators of the latter, which is widely used in the Lawra area, could not be reached to give this researcher the reason for their choice. Nonetheless, as a revision of the 1971 edition of the Revised Standard Version that employs an "essentially literal" translation "philosophy" (www.esv.org), their reason for adopting it as source text may not be very far from being the same as their earlier colleagues'. Interestingly, it was observed that dialectical differences in the two texts are insignificant. This is because, for purposes of wider acceptability by the targeted readership, the central Dagaare dialect spoken in Jirapa and surrounding areas was adopted in both versions.

\section{Purpose of study}

This study sought to examine following naturalness-related issues: How the translators rendered English proverbs in Dagaare; Which proverbs translate well between English and Dagaare; How parallel proverbs were used in the Dagaare text; How non-proverbial expressions were translated as proverbs in the RL and vice versa; and How connotative proverbs used in the Dagaare text are rendered. 
The two main questions that guided this study are:

1. Do the proverbs used in the Dagaare NT sound natural?

2 Do the proverbs with low naturalness compromise the quality of the translation?

Specifically, the study considered the following pertinent questions:

1. Are the natural ones exactly the same as the English ones or are they cultural equivalents?

2. For those that are less natural,

a) Why are they so?

b) What is missing in them?

c) Are there cultural equivalents for them in Dagaare?

d) What will be the natural forms?

3. Are there any of the English proverbs that are alien to Dagaare? If so, how best could they have been translated?

Another interesting question that could be examined in future research would be whether some of the expressions labelled as 'proverbs' are not just mere adages or aphorisms or axioms or maxims and do not qualify to be 'proverbs'.

\section{Significance of study}

This study is significant in the sense that it is the first of its kind as far as the examining of naturalness in proverbs used in the Dagaare New Testament (and probably the whole Bible) is concerned. Various Bible publishers have a specific number of years that a particular version of the Bible must be in circulation before it is revised. Bibles International (BI), publishers of one of the Dagaare texts used in this study, require at least 10 years. That means that, the Naaymen Nolay Paalaa, which was published in 2015 by BI should be due for review in five years. Since proverbs constitute a major part of the discourse of both the Dagaaba and Hebrews, findings of this research would be very beneficial to reviewers that will work on this and other versions in the near future. The study also provides another window for scholars interested in cultural and linguistic study of African languages to peep into Dagaare culture. As John Mbiti once observed: "Where and when the gospel is proclaimed, it cannot be removed from the cultural letters all around us, since you cannot have the gospel in a vacuum ... One of the vital cultural elements in Africa is the proverb" (Mbiti, 1995:1). Mbiti bemoans 
Dansieh, S.A./Legon Journal of the Humanities Vol. 30.1 (2019)

the abandonment and disuse of proverbs in theological discourses, given the acknowledged enviable place that proverbs occupy in African culture. A study that seeks to contribute to the use of these important cultural communicative devices should therefore be very significant.

\section{Methodology}

Data for this study were obtained mainly from secondary sources and comprised two versions of the New Testament in Dagaare - Naaymen Nopaalaa Gane (Bible Society of Ghana, 2014) and the Naaymen Nolay Paalaa (Bibles International, 2015). The New Revised Standard Version (NRSV, 1999) and the English Standard Version (ESV, 2001) served as the source texts. Over 100 proverbs were identified from the Dagaare New Testament. Out of the number, 42 proverbs were selected based on their similarity to the source text proverbs in English. These were subsequently compared with their renderings in the Dagaare (RL) text to determine their degree of naturalness. Both online and library sources were also used in this study. Personal interaction with the translators and some users of the Dagaare NT also yielded valuable information on the naturalness of proverbial and idiomatic biblical verses translated into Dagaare from English. The data obtained was compiled and tabulated. Proverbs compiled were then subjected to analysis in the receptor language (RL) to assess the extent of their naturalness by ticking in the appropriate column on the scale: Natural - Near Natural - Less Natural.

The 42 proverbs identified in the source text in English were compared with their renderings in the Dagaare (RL) texts to determine their extent of naturalness, using native speaker intuition. Admittedly, the list of proverbs sampled cannot be said to be exhaustive; however, considering the scope of this paper, it was considered representative enough for the intended analysis. The sampled proverbs were read out to members of selected churches in the Wa Municipality where the two versions of the Dagaare NT have been in use since their dedication in 2014 and 2015 respectively. The translators were subsequently interviewed to find out whether, if they were given a second chance, they would translate those proverbs differently or maintain their earlier renderings. 


\section{Previous studies}

\section{Rhetorical tensions on defining key quality concepts in Bible}

\section{Translation}

The topic of determining translation quality has been a subject of debate for decades with the possibility of ever arriving at a consensus on a universally acceptable definition remaining elusive. Traditionally, three main criteria have been in use: accuracy, clarity and naturalness (Barnwell, 1992:23). In recent times some other benchmarks for assessing the quality of translation have been introduced. Anderson (1998:1) for instance proposed a fourth criterion - "the criterion of perceived authenticity." In relating this criterion to the other three, he defines "perceived authenticity" as "the receptor audience's perception that the text is an authentic and trustworthy version of the original message." He based his addition of the fourth criterion on the premise that many controversies about translation, such as the debate about literal translation versus dynamic equivalence, are really debates about authenticity, even though the debate is expressed in terms of accuracy. He argues that it is perceived authenticity that often causes translations to be accepted or rejected, and that it is authenticity that is implicitly used to judge translations. Mudge rather calls Anderson's "criterion of authenticity" the criterion of "acceptability," arguing that "the last critical quality of a good translation is acceptability" (Mudge, 1997:65). He emphasizes the importance of the target audience's acceptance of the translation as an accurate and meaningful rendering of the original message. Acknowledging the relevance of acceptability theory, Larson (2001:44) asserts that "acceptability should be a major concern to translators" as the absence of this benchmark in a text could result in the receptor audience rejecting the translation. As Daams (2015) rightly observes, the merit of translation must not only be based on it being good quality; it must also be perceived to be good quality by the target audience.

Writing onnaturalness and artificiality in Bioethics, Schiemannalso adds an interesting twist to the quality-translation debate - "Naturalness" and "artificiality". He argues that:

[n]aturalness and artificiality form an unlikely pair. While the expression "natural" is usually connected with positive attributes, "artificial", as a rule has negative connotations. "Natural"suggests obviousness, selfevidence, genuineness or harmoniousness, whereas "artificial" implies complicatedness, lack of clarity, inauthenticity or incoherence (Schiemann, 2011: 99). 


\section{Naturalness}

A key criterion for establishing the quality of any translation project is that it must attain the naturalness standard; that is, it must sound natural. The subject of naturalness dates back to the days of St. Jerome and his followers like Luther (1530) amd Dryden (1684), who advocated for "colloquial and natural renderings of texts." Following this, other translation authorities endeavoured to produce translation works that they considered "natural as much as possible" and stressed the need for a natural translation.They includedTyter (1797); Beloc (1931); Nida (1943) and Jakobson (1959). A brief note on two of them just to affirm their strong stance on the subject is offered here: First, Tyter (1797) is acknowledged as one who advocated that in order to achieve a natural translation, a translator must be free in adding to or retrenching from the original text when it is being translated into a target language. Nida (1943), is cited as describing a translator, who aims at a natural translation, as one who "produces a total overall effect with approximate tone" where the intention of the text takes precedence over the words that the author uses and the author's understanding of the kind of target audience the original author had in mind (in Fadaee, 2011:201).

In recent times, it has been the practice in naturalness theory to view all distinctions in language as scales (Fadaee, 2011). Entities on each scale differ in naturalness, the end points of each scale being the most natural and least natural respectively. The terms "more natural" and "less natural" make it possible to avoid the logically contradictory terms "natural" and "unnatural". Fadaee argues that "unnatural" cannot seriously be predicated of anything in a natural language. He however concedes that the word occurs occasionally in theoretical writings.

\section{Accuracy}

Accuracy of translation implies that a translated text communicates the same meaning as the source text. A translation that tends to omit some pieces of information, adds information that is not actually in the source language, or contains errors in analysing the source text and consequently producing a different meaning cannot be accepted as accurate (Rahimi, 2004).

\section{Clarity}

According to Larsen (2001), "clearness in translation means that the translated piece can communicate to the people (target audience) who are 
to use it. In his view, the forms of the language used in a clear translation should be those which make the message of the source text as easy to understand as the source text itself was to understand. Thus, a translation's quality is compromised if it:

1. Fails to communicate to the people who use it;

2. Does not use the form of language that is understandable by the speakers.

(Rahimi, 2004:56).

This paper focuses on naturalness in translating, but it was deemed necessary to briefly introduce the concepts of clarity and accuracy, considering their inter-relatedness to naturalness.

\section{Proverbs}

The word proverb originated from the Latin word proverbium, meaning "saying" (www.latin-dictionary.org 2008). A proverb is usually a short and pithy saying that states a general truth or piece of advice and is often metaphorical. It is also said to be a simple and concrete saying that is popularly known and repeated. It expresses a truth based on common sense or experience. Proverbs are culture-specific but oftentimes one may find similarities in wording and the underlying concepts between two languages. It has also been observed that proverbs are often borrowed from similar languages and cultures, and sometimes come down to the present through more than one language. Proverbs are context-specific and using them out of context or at the wrong time is usually frowned upon (Ojoade, 1983).Yankah, in an earlier study, argued that "in the absence of context, proverbial wit cannot be determined" (Yankah, 1982:145). He acknowledged the value of "verbal wit" in Africa and underscored the pervasiveness of its use by saying that "the proverb is employed in everyday discourse, and is probably the most spontaneous of all the expressive art forms in Africa." He further noted that people from all walks of life: "orators, preachers, litigants, debaters, elders and participants in ordinary discourses normally consider it a mark of traditional sophistication to spice their speech with proverbs." As far as context is concerned, he argues that writing and speaking require different skills and that whereas "oral use of the proverb is spontaneous, literary use is not." This does not suggest that proverbs are not used in African literary works or should not be used in works (such as the Bible) translated into these languages from non-African languages. The non-spontaneity of proverbs, when it comes to literary use, is not surprising 
because the concept of literacy itself in most African communities is arguably a recent development. Proverbs may also be expressed on drums, through gestures, in dancing and through visual art symbols (Yankah, 1982:144). As far as their use in other media like those cited by Yankah is concerned, the practice is as old as the cultures themselves.

Interpreting proverbs in the same language has never been an easy job, even for persons aclaimed by local folks to be knowlegeable in them. The task of interpreting proverbs across cultures naturally becomes much more difficult. Hashemi (2009:1) observes that "All languages have particular terminology, some of which are deeply rooted in the culture of the speakers of the specific language; consequently, they can pose unique difficulties in the comprehension of culture specific texts."The Bible, by virtue of it being a historical and cultural book is replete with proverbs, and so is formal Dagaare discourse. Interestingly, a lot of similarities can be observed between Hebrew and Dagaare cultures. One classic example is the Hebrew levirate marriage mandated by Deuteronomy 25:5-6 obliging a surviving brother of a man who dies childless to marry the widow of his childless deceased brother. Similarly, as part of the complex patriarchal inheritance system of the Dagaaba, a surviving brother can inherit a deceased brother's properties, including his widow. The cleansing rites of the Hebrews and the Dagaaba also show striking similarities, especially in their use of specific birds and the hyssop for cleansing. It would therefore be interesting to explore possible similarities and differences that may exist in their use of proverbs too.

\section{Proverbs as instruments for culturo-religious dialogue}

The relationship between African proverbs and the Gospel has been likened, at one point, to a bridge and at another to a window. One author that addresses the subject extensively is Van Heerden (2013). In his interesting article entitled: "The Proverb is the Drum of God": On the Use of African Proverbs in the Interaction between African Culture and the Christian Faith", he credits Coter (1997) with the bridge metaphor, and Bernett (1997) with that of the window. The latter, for instance, is quoted as saying:

The question is: How do we communicate biblical values, the values contained in the gospel at a people's worldview level? I suggest that we must find a window, an access point into their worldview. One window into a people's worldview can be found and developed through an analysis of their traditional proverbial lore. Once we have sufficiently understood the 
nature of the window, we can then build communication bridges through this window between worldview values and biblical values. (Bernett, 1997 in van Heerden, 2013:465)

According to van Heerden, the metaphors suggest that proverbs constitute a framework for facilitating open communication in the midst of cultural gaps. He sees them as instruments for the provision of a language which enhances meaningful communication of the Bible. Among all the various metaphors used to illustrate the culturo-religious dialogue between African proverbs and the Gospel, van Heerden acknowledges one Anne NasimyuWasike for what he calls "the most striking metaphor" - 'the unwritten Bible' of the African people"(van Heerden, 2013). These metaphorical characteristics of proverbs were arrived at based on a long period of observation of proverb use on the continent. Another interesting but delicate area for the translator to consider is to be able to determine whether some of the sayings are not mere adages or aphorisms or axioms or maxims rather than 'proverbs'. To translate a text that would be accepted by the people as natural, accurate, clear and authentic, the appropriate use of proverbs would play a key role.

\section{Findings}

The focus of this study has been on naturalness in translating English proverbs into Dagaare, using the NRSV (1999) and the ESV (2001) as the English source texts and the Dagaare NT as RL text. Dressler's (2003) theory of naturalness which is said to evaluate translation quality in subjective terms with the criteria: "more natural" and "less natural" implying the existence of standards of comparison: a translation $x$ is more or less natural than $y$ was adopted. Proverbial and idiomatic biblical verses translated into Dagaare from English were compiled and tabulated as follows:

Table 1: Biblical verses considered proverbial

\begin{tabular}{|c|c|c|c|}
\hline $\mathbf{S} / \mathbf{N}$ & Proverbs/Idioms & $\begin{array}{l}\text { Source Text Ver- } \\
\text { sion in English }\end{array}$ & $\begin{array}{l}\text { Receptor Language Text } \\
\text { Version in Dagaare with } \\
\text { Gloss }\end{array}$ \\
\hline 1. & $\begin{array}{l}\text { An eye for an eye and } \\
\text { tooth for a tooth }\end{array}$ & $\begin{array}{l}\text { Mtt. 5:38: An eye } \\
\text { for eye, a tooth for } \\
\text { a tooth. }\end{array}$ & $\begin{array}{l}\text { Nimirinayso la nimiri sane, } \\
\text { kanyene, mey na yso la nyenee } \\
\text { sane. } \\
\text { Eye Fut. Pay Fact. Eye debt } \\
\text { Conj. tooth also Fut. Pay Fact. } \\
\text { Tooth debt. }\end{array}$ \\
\hline 2. & To go the extra mile & $\begin{array}{l}\text { Mtt. 5:41: Go the } \\
\text { extra mile }\end{array}$ & $\begin{array}{l}\text {...vey ka fo gaa macle ayi ne o } \\
\text {...let that you go mile two Conj } \\
3^{\text {rd }} \text { Pers. Sing. }\end{array}$ \\
\hline
\end{tabular}


Dansieh, S.A./Legon Journal of the Humanities Vol. 30.1 (2019)

\begin{tabular}{|c|c|c|c|}
\hline 3 . & $\begin{array}{l}\text { To wash one's hands off a } \\
\text { matter }\end{array}$ & $\begin{array}{l}\text { Mtt. 27:24 Wash } \\
\text { your hands of the } \\
\text { matter }\end{array}$ & $\begin{array}{l}\text {...ka o de kos a neba nine ene a } \\
\text { prge o nuuri... } \\
\text { Conj. he take water Def. people } \\
\text { eye on Conj. wash } 3{ }^{\text {rd }} \text { Pers. Sing. } \\
\text { hand+pl. }\end{array}$ \\
\hline 4. & $\begin{array}{l}\text { To cast pearls before } \\
\text { swine }\end{array}$ & $\begin{array}{l}\text { Mtt. 7: } 6 \text { To give } \\
\text { dogs what is holy. }\end{array}$ & $\begin{array}{l}\text { Ta ko bare boy nay e bonsoy, } \\
\text { bee los yc lepcl-veclaa ey do- } \\
\text { baare pos. } \\
\text { Imp.Neg.givedog+Pl.thing } \\
\text { which be thing-good Conj. } \\
\text { throw Your pearl+beautiful put } \\
\text { pig-Pl. inside. }\end{array}$ \\
\hline 5. & $\begin{array}{l}\text { To cast the first stone/ } \\
\text { People who live in glass } \\
\text { houses must not throw } \\
\text { stones. }\end{array}$ & $\begin{array}{l}\text { Jn. 8:7: Cast the } \\
\text { first stone }\end{array}$ & $\begin{array}{l}\text { A soba na zaa nay ba taa yel- } \\
\text { bieri a ycpos, ye vey ka o de wee } \\
\text { de kuurii za ney a pogo } \\
\text { Def. fellow Spec. all that Neg. } \\
\text { have deed+badYou+Pl. let him } \\
\text { take lead take stone throw Prep. } \\
\text { Def. woman }\end{array}$ \\
\hline 6. & $\begin{array}{l}\text { In/By the twinkling of } \\
\text { an eye }\end{array}$ & $\begin{array}{l}\text { I Cor. } 15: 50-52 \text { In } \\
\text { the twinkling of an } \\
\text { eye }\end{array}$ & $\begin{array}{l}\text {...a nimiri zaynoo pos... } \\
\text {... Def. eye blinking inside }\end{array}$ \\
\hline 7. & To fall from grace to grass & $\begin{array}{l}\text { Gal. 5:4: Fall from } \\
\text { grace }\end{array}$ & $\begin{array}{l}\text {...yc le la yi a nondeteroo sobiri } \\
\text { pos } \\
\text {... You-Pl. fall Fact. From Def. } \\
\text { mouth-take-give road inside }\end{array}$ \\
\hline 8. & $\begin{array}{l}\text { Do not muzzle out the ox } \\
\text { that treads the grain. }\end{array}$ & $\begin{array}{l}\text { I Cor. 9:9; I Tim } \\
\text { 5:18 Do not muzzle } \\
\text { out the ox that } \\
\text { treads out the } \\
\text { grain. }\end{array}$ & $\begin{array}{l}\text {..ta le a nakuoraa na nosre nay } \\
\text { nebrc a bombie. } \\
\text { Neg. tie Def. cow-farmer mouth } \\
\text { that stepping-on Def grain. }\end{array}$ \\
\hline 9. & $\begin{array}{l}\text { Bad company ruins good } \\
\text { morals }\end{array}$ & $\begin{array}{l}\text { I Cor. } 15: 33 \text { Bad } \\
\text { company ruins } \\
\text { good morals. }\end{array}$ & $\begin{array}{l}\text { Tutaafaare may saay la evecle. } \\
\text { Follow-fellow bad Hab. Spoil } \\
\text { Spec. Deed+good }\end{array}$ \\
\hline 10. & $\begin{array}{l}\text { If the blind leadthe blind, } \\
\text { both will fall in a pit }\end{array}$ & Mtt.15:14 & $\begin{array}{l}\text { Ka zoy wa tagra zon, ba zaa } \\
\text { bayi na lay le la a bog pos. } \\
\text { Cond.Blind-person+Emph. } \\
\text { Pull+Prog. Blind-person they all } \\
\text { two Fut. together fall Def. ditch } \\
\text { inside. }\end{array}$ \\
\hline 11. & $\begin{array}{l}\text { No city or house divided } \\
\text { against itself will stand }\end{array}$ & Mtt 12:25 & $\begin{array}{l}\text { Yiri na zaa nay poy kyaare ne o } \\
\text { meyc koy tos are. } \\
\text { House/Town Spec. all that di- } \\
\text { vide towards with } 3^{\text {rd }} \text { Pers. Sing } \\
\text { Pron. Fut. Neg. be-able stand. }\end{array}$ \\
\hline
\end{tabular}


Dansieh, S.A./Proverbs and naturalness in mother-tongue translation

\begin{tabular}{|c|c|c|c|}
\hline 12. & The Son of man & Mtt 8:20; Lk 9:58 & $\begin{array}{l}\text { Nensaala Bid»o Person+weak } \\
\text { child+male (Dos bie/ninsaalaa } \\
\text { bie) }\end{array}$ \\
\hline 13. & Signs of the times & & $\begin{array}{l}\text { A baroo say mannoo (Nya- } \\
\text { laanyiili) } \\
\text { Def. ending time illustration. }\end{array}$ \\
\hline 14. & The eleventh hour & Mtt 20:6-8 & $\begin{array}{l}\text { Zimanee gogori anuu say } \\
\text { (Sayparaa puoriy, meaning too } \\
\text { late) Evening bell+Pl. } 5 \text { period. }\end{array}$ \\
\hline 15 . & Den of thieves & $\begin{array}{l}\text { Mtt 21:13; Mk 11:17; } \\
\text { Lk 19:46 }\end{array}$ & $\begin{array}{l}\text { Nanyigiri die(Nanyigi baa) } \\
\text { Thieves+Pl room }\end{array}$ \\
\hline 16. & Sounding your trumpet & Mtt 6:2 & $\begin{array}{l}\text { Pecle eele (fara bara) Blow- } \\
\text { Prog. Horn }+ \text { Pl. }\end{array}$ \\
\hline 17. & $\begin{array}{l}\text { All who take the sword } \\
\text { will perish by the sword. }\end{array}$ & Mtt. 26:52 & $\begin{array}{l}\text { Balay nay vos a sos na bore we } \\
\text { la a sos ey } \\
\text { They-who that pull-out Def. } \\
\text { knife Fut. Get-lost waste Perf. } \\
\text { Def. knife on }\end{array}$ \\
\hline 18. & $\begin{array}{l}\text { The stone that the build- } \\
\text { ers rejected, has become } \\
\text { the cornerstone. }\end{array}$ & Mtt 21:42 & $\begin{array}{l}\text { A kuuri na memecrebs nay za- } \\
\text { gre, waa la a gongonaa zukuuri } \\
\text { Def. stone which Def. } \\
\text { build+builders Perf. reject be } \\
\text { Fact. Def. bend-bend head } \\
\text { stone. }\end{array}$ \\
\hline 19. & Straight and narrow. & Mtt.7:14 & $\begin{array}{l}\text { Kyc a sobiri nay gcre a Nyəvore } \\
\text { zie ne a be dendsree la bile }\end{array}$ \\
\hline 20. & $\begin{array}{l}\text { No man seweth a piece } \\
\text { of new cloth on an old } \\
\text { garment. }\end{array}$ & Mk2:21 & $\begin{array}{l}\text { Nec bamay de pempaala a liiri } \\
\text { ne kparekora. } \\
\text { Person Neg. Hab. Take new- } \\
\text { cloth Prep. Sew-on with dress- } \\
\text { old. }\end{array}$ \\
\hline 21. & Good Samaritan & Lk 10:30-37 & $\begin{array}{l}\text { Samaria Dosvelaa (Nensopbie) } \\
\text { Samaria Man-good }\end{array}$ \\
\hline 22. & $\begin{array}{l}\text { Breathed His last/He } \\
\text { gave up the ghost }\end{array}$ & Lk 23:46 & $\begin{array}{l}\text { Voore O vooroy pare baara. } \\
\text { Breathe } 3^{\text {rd }} \text { Pers. Sing. source } \\
\text { ending }\end{array}$ \\
\hline 23. & Eat, drink and be merry & Lk 12:19 & $\begin{array}{l}\text { Dire, nyuuro, a nycre popecloy } \\
\text { Eat+Prog. Drin+Prog. Conj. } \\
\text { See+Prog. Stomach-white (Dire, } \\
\text { nyuuro, a kuolo) }\end{array}$ \\
\hline 24. & See the light & Lk 11:33 & $\begin{array}{l}\text { Nycre a kyaane } \\
\text { See+Prog. Def. light (Possible } \\
\text { interpretation of the neg. being } \\
\text { stupid) }\end{array}$ \\
\hline
\end{tabular}


Dansieh, S.A./Legon Journal of the Humanities Vol. 30.1 (2019)

\begin{tabular}{|c|c|c|c|}
\hline 25 . & Not lose heart & Lk 18:1 & $\begin{array}{l}\text { Ta bale } \\
\text { Imp. Neg. Be+tired (pos saay/ } \\
\text { ena kyoore) may be better } \\
\text { sometimes }\end{array}$ \\
\hline 26. & Divided we fall & Lk 11:17 & 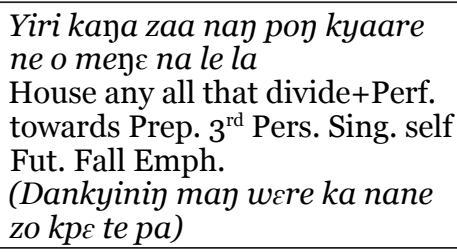 \\
\hline 27. & A cross you have to bear & Lk 14:27 & $\begin{array}{l}\text { Tuo dagara } \\
\text { Carry wood+cross }\end{array}$ \\
\hline 28. & $\begin{array}{l}\text { Don't judge by appear- } \\
\text { ances }\end{array}$ & Jn 7:24: 2 Cor 10:7 & $\begin{array}{l}\text { Kaara le nensaala nay waa kye } \\
\text { dire o sarec } \\
\text { Watch how weak-person Emph. } \\
\text { Be Conj. Eat+Prog. } 3{ }^{\text {rd }} \text { Pers. } \\
\text { Sing. judgment }\end{array}$ \\
\hline 29. & Cast the first stone. & Jn. 8:7 & $\begin{array}{l}\text { A soba na nay ba taa yelbieri } \\
\text { zaa a ye pos, ye ven ka o de wee } \\
\text { de kuurii za... } \\
\text { Def. fellow Emph. that Neg. } \\
\text { have deed-bad any Def. }{ }^{\text {nd }} \text { Pers. } \\
\text { Pl. inside } 2^{\text {nd }} \text { Pers. Pl. allow that } \\
3^{\text {rd }} \text { Pers. Sing. take lead take } \\
\text { stone throw. }\end{array}$ \\
\hline 30. & Circumcision of the heart & Rom 2:29 & $\begin{array}{l}\text { Yっ-ymaabo e la sukyiri bone. } \\
\text { Penis-cutting Pres.+Be Spec. } \\
\text { heart knowing. }\end{array}$ \\
\hline 31. & Risk your neck & Rom 16:4 & $\begin{array}{l}\text { De fo nysvore ko } \\
\text { Take } 2^{\text {nd }} \text { Pers. Sing. give. } \\
\text { (De zu bin ka ba ymaa) }\end{array}$ \\
\hline 32. & Twinkling of an eye & I Cor $15: 50-52$ & $\begin{array}{l}\text { A nimiri zaybo pos } \\
\text { Def. eye blink inside. }\end{array}$ \\
\hline 33. & A thorn in the flesh & 2 Cor $12: 7$ & $\begin{array}{l}\text { Goo da kysge ma la } \\
\text { Thorn prick me Perf. (Sayk- } \\
\text { pay-malee)Too literal }\end{array}$ \\
\hline 34. & Fall from grace & Gal. 5:4 & 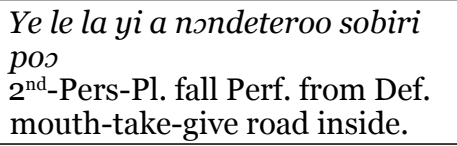 \\
\hline 35 . & $\begin{array}{l}\text { Whatever one sows, that } \\
\text { will he reap }\end{array}$ & Gal 6:7. & 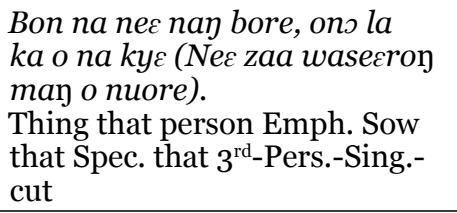 \\
\hline
\end{tabular}


Dansieh, S.A./Proverbs and naturalness in mother-tongue translation

\begin{tabular}{|c|c|c|c|}
\hline 36. & $\begin{array}{l}\text { The love of money is a } \\
\text { root of all kinds of evil. }\end{array}$ & I Tim. 6:10 & $\begin{array}{l}\text { Bonso libie nommo la a yelfaa } \\
\text { eroy yaga piilu zie. } \\
\text { What-cause money love be Def. } \\
\text { matter-bad deed plenty begin- } \\
\text { ning place. } \\
\end{array}$ \\
\hline 37. & $\begin{array}{l}\text { Does a spring pour forth } \\
\text { from the same opening } \\
\text { both fresh and salt wa- } \\
\text { ter?...Can a fig tree bear } \\
\text { olives, or a grapevine } \\
\text { produce figs? }\end{array}$ & James 3:11,12 & 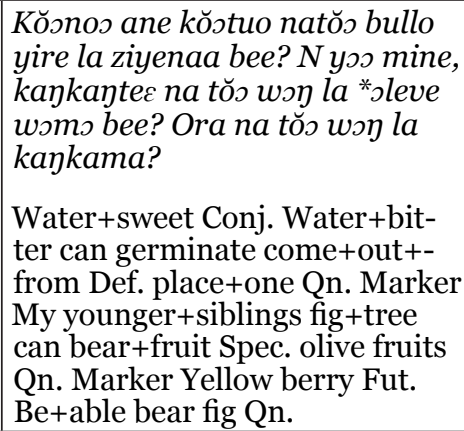 \\
\hline 38. & Wallowing in the mire & 2 Peter 2:22a & $\begin{array}{l}\text { Bille memere pos } \\
\text { Roll-over+Prog. Mud inside. }\end{array}$ \\
\hline 39. & $\begin{array}{l}\text { The dog returns to his } \\
\text { own vomit }\end{array}$ & 2 Peter 2:22b & $\begin{array}{l}\text { Baa may lec di la o meyc tïri. } \\
\text { Dog Hab. Turn-back eat Emph. } \\
3^{\text {rd }} \text { Pers. Sing. self vomit }\end{array}$ \\
\hline 40. & God speed & 2 Jn 1:11 & $\begin{array}{l}\text { Tuori } \\
\text { Meet }\end{array}$ \\
\hline 41. & Lukewarm & Rev 3:16a & $\begin{array}{l}\text { Ba waa maaroy bee toloy } \\
\text { Neg. be cold Conj. hot }\end{array}$ \\
\hline 42. & Spit out of & Rev. 3:16b & $\begin{array}{l}\text { Poore bare } \\
\text { Spew throw-away } \\
\text { (Poore/Toore bare, usually after } \\
\text { uttering a curse) }\end{array}$ \\
\hline
\end{tabular}


Dansieh, S.A./Legon Journal of the Humanities Vol. 30.1 (2019)

The 42 proverbs compiled were then subjected to analysis in the receptor language (RL) to assess the extent of their naturalness by checking (X) in the appropriate column on the scale: Natural -Near Natural - Less Natural. The results are presented in Table 2.

Table 2: Extent of naturalness of identified proverbs translated into Dagaare

\begin{tabular}{|c|c|c|c|c|c|}
\hline $\mathbf{S} / \mathbf{N}$ & $\begin{array}{l}\text { Source } \\
\text { Text Ver- } \\
\text { sion in } \\
\text { English }\end{array}$ & RL Version & $\begin{array}{l}\text { Degree of } \\
\text { Natural- } \\
\text { ness: } \\
\text { 1.Natural }\end{array}$ & $\begin{array}{l}\text { Degree of } \\
\text { Natural- } \\
\text { ness: } \\
\text { 2. Near } \\
\text { Natural }\end{array}$ & $\begin{array}{l}\text { Degree of } \\
\text { Natural- } \\
\text { ness: } \\
\text { 3. Less } \\
\text { Natural }\end{array}$ \\
\hline 1. & $\begin{array}{l}\text { Mtt. } 5: 38 \\
\text { An Eye for } \\
\text { an eye, and } \\
\text { a tooth for a } \\
\text { tooth. }\end{array}$ & $\begin{array}{l}\text { Nimiri na yəs la } \\
\text { nimiri sane, ka } \\
\text { nyene, mey na yəo } \\
\text { la nyenee sane. } \\
\text { Eye Fut. Pay-for } \\
\text { Fact. eye debt } \\
\text { Conj. tooth Fut. } \\
\text { pay-for tooth debt }\end{array}$ & & $\mathrm{X}$ & \\
\hline 2. & $\begin{array}{l}\text { Mtt. 5:41 } \\
\text {...go with } \\
\text { him two } \\
\text { (i.e. To go } \\
\text { the extra } \\
\text { mile) }\end{array}$ & $\begin{array}{l}\text {...vey ka fo gaa } \\
\text { mecle ayi ne o } \\
\text { Let-that } 2^{\text {nd }} \text { Pers.- } \\
\text { Sing. go mile two } \\
\text { with him }\end{array}$ & & $\mathrm{X}$ & \\
\hline 3. & $\begin{array}{l}\text { Mtt } 27: 24 \\
\ldots \text { washed } \\
\text { his hands of } \\
\text { the matter }\end{array}$ & $\begin{array}{l}\text {...ka o de kos...a } \\
\text { pege o nuuri... } \\
\text { Conj. } 2^{\text {nd }} \text {-Pers.- } \\
\text { Sing. take water } \\
\text { Conj. wash } 2^{\text {nd- }} \\
\text { Pers.-Sing. hand }\end{array}$ & $\mathrm{X}$ & & \\
\hline 4. & $\begin{array}{l}\text { Mtt 7: } 6 \\
\text { Do not give } \\
\text { dogs what } \\
\text { is holy (=To } \\
\text { cast pearls } \\
\text { before } \\
\text { swine KJV) }\end{array}$ & $\begin{array}{l}\text { Ta ko bare boy } \\
\text { nay e bonsoy, bee } \\
\text { los ye lepsl-veclaa } \\
\text { ey dobaare poo. } \\
\text { Imp.+Neg. take- } \\
\text { give thing that } \\
\text { be thing-good } \\
\text { pig+dog-Pl. inside }\end{array}$ & & $\mathrm{X}$ & \\
\hline
\end{tabular}


Dansieh, S.A./Proverbs and naturalness in mother-tongue translation

\begin{tabular}{|c|c|c|c|c|c|}
\hline 5. & $\begin{array}{l}\text { Jn. } 8: 7 \\
\text { Be the first } \\
\text { to throw a } \\
\text { stone at. }\end{array}$ & $\begin{array}{l}\text { A soba na zaa nay } \\
\text { ba taa yelbieri a } \\
\text { ye pos, ye vey ka } \\
\text { o de wee de kuurii } \\
\text { zaney a pogo } \\
\text { Take lead take } \\
\text { stone throw }\end{array}$ & $\mathrm{X}$ & & \\
\hline 6. & $\begin{array}{l}\text { I Cor 15:50- } \\
52 ; \text { Eph } \\
6: 12 \\
\text { In the twin- } \\
\text { kling of an } \\
\text { eye }\end{array}$ & $\begin{array}{l}\text {... a nimiri zaynoo } \\
\text { pos... } \\
\text { Def. eye blinking } \\
\text { inside }\end{array}$ & & $\mathrm{X}$ & \\
\hline 7. & $\begin{array}{l}\text { Gal. 5:4 } \\
\text { Fallen away } \\
\text { from grace. } \\
\text { (To fall } \\
\text { from grace) }\end{array}$ & $\begin{array}{l}\text {.. ye le la yi a } \\
\text { nondeteroo sobiri } \\
\text { pos. } \\
2^{\text {nd-Pers.-Pl. fall }} \\
\text { Fact. from road } \\
\text { inside }\end{array}$ & & & $\mathrm{X}$ \\
\hline 8. & $\begin{array}{l}\text { I Cor 9:9 I } \\
\text { Tim 5:18 } \\
\text { You shall } \\
\text { not muzzle } \\
\text { out an ox } \\
\text { when it } \\
\text { treads out } \\
\text { the grain. }\end{array}$ & $\begin{array}{l}\text {...ta le a nakuoraa } \\
\text { na nosre nay } \\
\text { ncbre a bombie. } \\
\text { Imp.-Neg. tie } \\
\text { cow-farmer Comp. } \\
\text { stepping-on } \\
\text { things-seed }\end{array}$ & & & $\mathrm{X}$ \\
\hline 9. & $\begin{array}{l}\text { I Cor 15: } 33 \\
\text { Bad } \\
\text { company } \\
\text { ruins good } \\
\text { morals. }\end{array}$ & $\begin{array}{l}\text { Tutaafaare may } \\
\text { saay la evecle. } \\
\text { Following+one-an- } \\
\text { other+bad Hab. } \\
\text { Spoil Fact deeds- } \\
\text { good }\end{array}$ & & $\mathrm{X}$ & \\
\hline 10. & $\begin{array}{l}2 \text { Peter } 2: 22 \\
\text { The dog re- } \\
\text { turns to its } \\
\text { own vomit. }\end{array}$ & $\begin{array}{l}\text { Baa maj les di la o } \\
\text { meye tiiri } \\
\text { Dog Hab. turn eat } \\
3^{\text {rd Pers. Sing. own }} \\
\text { vomit }\end{array}$ & $\mathrm{X}$ & & \\
\hline
\end{tabular}


Dansieh, S.A./Legon Journal of the Humanities Vol. 30.1 (2019)

\begin{tabular}{|c|c|c|c|c|c|}
\hline 11. & $\begin{array}{l}\text { Mtt.15:13- } \\
14 \\
\text { The blind } \\
\text { leading the } \\
\text { blind. }\end{array}$ & $\begin{array}{l}\text { Ka zəy wa ta- } \\
\text { gra zon, ba zaa } \\
\text { bayi na lay le } \\
\text { la a bog pos. } \\
\text { Cond.Blind-per- } \\
\text { son+Emph. } \\
\text { Pull+Prog. } \\
\text { Blind-person they } \\
\text { all two Fut. togeth- } \\
\text { er fall Def. ditch } \\
\text { inside. }\end{array}$ & $\mathrm{X}$ & & \\
\hline 12. & $\begin{array}{l}\text { Mtt 12:25 } \\
\text { A house } \\
\text { divided } \\
\text { against } \\
\text { itself }\end{array}$ & $\begin{array}{l}\text { Yiri na zaa nay } \\
\text { poy kyaare ne o } \\
\text { meyc koy too are. } \\
\text { (Dankyiniy may } \\
\text { were ka nane zo } \\
\text { kpste pa) } \\
\text { House/Town Spec. } \\
\text { all that divide } \\
\text { towards with } 3^{\text {rd }} \\
\text { Pers. Sing Pron. } \\
\text { Fut. Neg. be-able } \\
\text { stand. }\end{array}$ & & $\mathrm{X}$ & \\
\hline 13 & $\begin{array}{l}\text { Mtt 8:20; } \\
\text { Lk 9:58 } \\
\text { The Son of } \\
\text { man }\end{array}$ & $\begin{array}{l}\text { Nensaala Bidso } \\
\text { Person+weak } \\
\text { child+male (Dos } \\
\text { bie/ninsaalaa bie) }\end{array}$ & & $\mathrm{X}$ & \\
\hline 14. & $\begin{array}{l}\text { Mtt. 10:6 } \\
\text { Signs of the } \\
\text { times }\end{array}$ & $\begin{array}{l}\text { A baroosay man- } \\
\text { noo Def. ending+- } \\
\text { time illustration. }\end{array}$ & & & $\mathrm{X}$ \\
\hline 15. & $\begin{array}{l}\text { Mtt 20:6-8 } \\
\text { The elev- } \\
\text { enth hour }\end{array}$ & $\begin{array}{l}\text { Zimanee gogori } \\
\text { anuu say } \\
\text { (Sayparaa puoriy) } \\
\text { Evening bell+Pl. } 5 \\
\text { period. }\end{array}$ & & $\mathrm{X}$ & \\
\hline 16. & $\begin{array}{l}\text { Mtt 21:13; } \\
\text { Mk 11:17; } \\
\text { Lk 19:46 } \\
\text { Den of } \\
\text { thieves }\end{array}$ & $\begin{array}{l}\text { Nanyigiri } \\
\text { die(Nanyigi baa) } \\
\text { Thieves+Pl room }\end{array}$ & & $\mathrm{X}$ & \\
\hline
\end{tabular}


Dansieh, S.A./Proverbs and naturalness in mother-tongue translation

\begin{tabular}{|c|c|c|c|c|}
\hline 17 . & $\begin{array}{l}\text { Mtt 6:2 } \\
\text { Sounding } \\
\text { your trum- } \\
\text { pet }\end{array}$ & $\begin{array}{l}\text { Pecle eele (fara } \\
\text { bara) Blow-Prog. } \\
\text { Horn+Pl. }\end{array}$ & & $\mathrm{X}$ \\
\hline 18. & $\begin{array}{l}\text { Mtt. } 26: 52 \\
\text { He who } \\
\text { lives by } \\
\text { the sword } \\
\text { dies by the } \\
\text { sword. }\end{array}$ & $\begin{array}{l}\text { Balay nay vos a } \\
\text { sos na borews la } \\
\text { a sos eyc They- } \\
\text { who that pull-out } \\
\text { Def. knife Fut. } \\
\text { Get+lost+waste } \\
\text { Perf. Def. knife on }\end{array}$ & & $\mathrm{X}$ \\
\hline 19. & $\begin{array}{l}\text { Mtt 21:42 } \\
\text { The stone } \\
\text { which the } \\
\text { builders } \\
\text { rejected, } \\
\text { the same } \\
\text { became the } \\
\text { head of the } \\
\text { corner. }\end{array}$ & $\begin{array}{l}\text { A kuuri na } \\
\text { msmesrebs nay } \\
\text { zagre, waa la a } \\
\text { gongonaazukuuri } \\
\text { Def. stone which } \\
\text { Def. build+build- } \\
\text { ers Perf. reject } \\
\text { be Fact. Def. } \\
\text { bend-Redup. head } \\
\text { stone. }\end{array}$ & $\mathrm{X}$ & \\
\hline 20. & $\begin{array}{l}\text { Mtt.7:14 } \\
\text { Straight and } \\
\text { narrow. }\end{array}$ & $\begin{array}{l}\text { Kyc a sobiri nay } \\
\text { gerc a Nyovore zie } \\
\text { ne a be dendsre e } \\
\text { la bile. }\end{array}$ & & $\mathrm{X}$ \\
\hline 21. & $\begin{array}{l}\text { Mk2:21 } \\
\text { No man } \\
\text { seweth a } \\
\text { piece of } \\
\text { new cloth } \\
\text { on an old } \\
\text { garment. }\end{array}$ & $\begin{array}{l}\text { Nec ba may de } \\
\text { pempaala a liiri ne } \\
\text { kparekora. } \\
\text { Person Neg. Hab. } \\
\text { Take new-cloth } \\
\text { Prep. Sew-on with } \\
\text { dress-old. }\end{array}$ & $\mathrm{X}$ & \\
\hline 22. & $\begin{array}{l}\text { Lk 10:30-37 } \\
\text { Good Sa- } \\
\text { maritan }\end{array}$ & $\begin{array}{l}\text { Samaria Dosvelaa } \\
\text { (Nensoy bie) } \\
\text { Samaria Man-good }\end{array}$ & & $\mathrm{X}$ \\
\hline
\end{tabular}


Dansieh, S.A./Legon Journal of the Humanities Vol. 30.1 (2019)

\begin{tabular}{|c|c|c|c|c|}
\hline 23. & $\begin{array}{l}\text { Lk 23:46 } \\
\text { He gave up } \\
\text { the ghost }\end{array}$ & $\begin{array}{l}\text { Voore O vooroy } \\
\text { pare baara. } \\
\text { Breathe } 3^{\text {rd }} \text { Pers. } \\
\text { Sing. source end- } \\
\text { ing } \\
\text { (On daay ymaa } \\
\text { vooroy/ On daay } \\
\text { kpi) Possible } \\
\text { cultural misin- } \\
\text { terpretation of } \\
\text { "give up the ghost" } \\
=: \text { sez yi (meaning } \\
\text { one's soul leaving } \\
\text { the body and can } \\
\text { be brought back } \\
\text { through rituals). }\end{array}$ & & $\mathrm{X}$ \\
\hline 24. & $\begin{array}{l}\text { Lk 12:19 } \\
\text { Eat, drink } \\
\text { and be } \\
\text { merry }\end{array}$ & $\begin{array}{l}\text { Dire, nyuuro, a } \\
\text { nycre popecloy } \\
\text { Eat+Prog. } \\
\text { Drin+Prog. Conj. } \\
\text { See+Prog. Stom- } \\
\text { ach-white (Dire, } \\
\text { nyuuro, a kuolo) }\end{array}$ & & $\mathrm{X}$ \\
\hline 25 . & $\begin{array}{l}\text { Lk 11:33 } \\
\text { See the light }\end{array}$ & $\begin{array}{l}\text { Nycre a kyaane } \\
\text { See+Prog. Def. } \\
\text { light (Possible } \\
\text { interpretation of } \\
\text { the Neg. will mean } \\
\text { 'to be stupid') }\end{array}$ & $\mathrm{X}$ & \\
\hline 26. & $\begin{array}{l}\text { Lk 18:1 } \\
\text { Not lose } \\
\text { heart }\end{array}$ & $\begin{array}{l}\text { Ta bale } \\
\text { Imp. Neg. Be+tired } \\
\text { (ta ven ka pos } \\
\text { saay/ena kyoore, } \\
\text { literally: Imp. Neg. } \\
\text { let (your) stom- } \\
\text { ach spoil/body } \\
\text { be weak) may be } \\
\text { better. }\end{array}$ & $X$ & \\
\hline
\end{tabular}


Dansieh, S.A./Proverbs and naturalness in mother-tongue translation

\begin{tabular}{|c|c|c|c|c|}
\hline 27. & $\begin{array}{l}\text { Lk 11:17 } \\
\text { Divided we } \\
\text { fall }\end{array}$ & $\begin{array}{l}\text { Yirikangzaanang } \\
\text { pong kyaare ne } \\
\text { mengena le la } \\
\text { House any all } \\
\text { that divide+Perf } \\
\text { towards Prep. } 3^{\text {rd }} \\
\text { Pers. Sing. self Fut. } \\
\text { Fall Emph. }\end{array}$ & & $\mathrm{X}$ \\
\hline 28 . & $\begin{array}{l}\text { Lk 14:27 } \\
\text { A cross you } \\
\text { have to bear }\end{array}$ & $\begin{array}{l}\text { Tuo dagara } \\
\text { Carry wood+cross }\end{array}$ & & $\mathrm{X}$ \\
\hline 29. & $\begin{array}{l}\text { Jn 7:24: } 2 \\
\text { Cor 10:7 } \\
\text { Don't judge } \\
\text { by appear- } \\
\text { ances }\end{array}$ & $\begin{array}{l}\text { Kaara le nensaala } \\
\text { nay waa kyc dire } \\
\text { o sarce Watch } \\
\text { how weak-person } \\
\text { Emph. Be Conj. } \\
\text { Eat+Prog. } 3 \text { rd Pers. } \\
\text { Sing. judgement }\end{array}$ & $\mathrm{X}$ & \\
\hline 30. & $\begin{array}{l}\text { Jn. 8:7 } \\
\text { Cast the } \\
\text { first stone. }\end{array}$ & 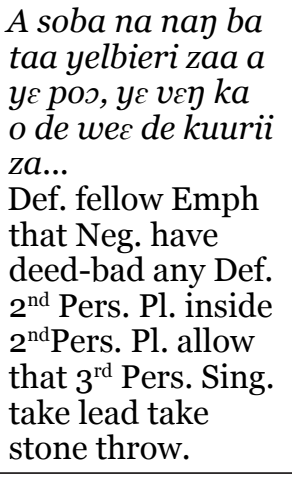 & $\mathrm{X}$ & \\
\hline 31. & $\begin{array}{l}\text { Rom 2:29 } \\
\text { Circumci- } \\
\text { sion of the } \\
\text { heart }\end{array}$ & $\begin{array}{l}\text { Yo-ymaabo e la } \\
\text { sukyiri bone. } \\
\text { Penis-cutting } \\
\text { Pres.+Be Spec. } \\
\text { heart knowing. }\end{array}$ & & \\
\hline
\end{tabular}


Dansieh, S.A./Legon Journal of the Humanities Vol. 30.1 (2019)

\begin{tabular}{|c|c|c|c|c|}
\hline 32. & $\begin{array}{l}\text { Rom 16:4 } \\
\text { Risk your } \\
\text { neck }\end{array}$ & $\begin{array}{l}\text { De fo nyovore ko } \\
\text { Take } 2^{\text {nd }} \text { Pers. Sing. } \\
\text { Nose+living give. } \\
\text { (De zu bin ka ba } \\
\text { ymaa Take head } \\
\text { put+down Comp. } \\
\text { they cut) }\end{array}$ & & $\mathrm{X}$ \\
\hline 33. & $\begin{array}{l}\text { I Cor 15:50- } \\
52 \\
\text { Twinkling } \\
\text { of an eye }\end{array}$ & $\begin{array}{l}\text { A nimiri zaybo pos } \\
\text { Def. eye blink } \\
\text { inside. }\end{array}$ & $\mathrm{X}$ & \\
\hline 34. & $\begin{array}{l}2 \text { Cor } 12: 7 \\
\text { A thorn in } \\
\text { the flesh }\end{array}$ & $\begin{array}{l}\text { Gos da kysge ma } \\
\text { la Thorn Past prick } \\
\text { me Perf. }\end{array}$ & & $\mathrm{X}$ \\
\hline 35. & $\begin{array}{l}\text { Gal. 5:4 } \\
\text { Fall from } \\
\text { grace }\end{array}$ & $\begin{array}{l}\text { Ye le la yi a nonde- } \\
\text { teroo sobiri pos } \\
2^{\text {nd-Pers-Pl. fall }} \\
\text { Perf. from Def. } \\
\text { mouth-take-give } \\
\text { road inside. }\end{array}$ & $\mathrm{X}$ & \\
\hline 36. & $\begin{array}{l}\text { Gal 6:7 } \\
\text { Whatsoev- } \\
\text { er a man } \\
\text { soweth, that } \\
\text { shall he also } \\
\text { reap. }\end{array}$ & 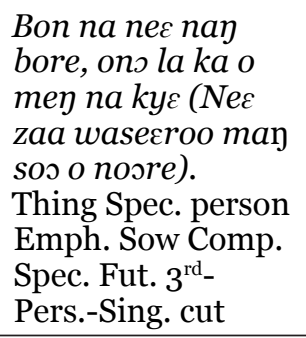 & $\mathrm{X}$ & \\
\hline 37. & $\begin{array}{l}\text { I Tim. } 6: 10 \\
\text { The love of } \\
\text { money is } \\
\text { the root of } \\
\text { all evil. }\end{array}$ & $\begin{array}{l}\text { Bonso libie nэmmo } \\
\text { la a yelfaa eroy } \\
\text { yaga piilu zie. } \\
\text { What-cause mon- } \\
\text { ey love be Def. } \\
\text { matter-bad deed } \\
\text { plenty beginning } \\
\text { place. }\end{array}$ & $\mathrm{X}$ & \\
\hline
\end{tabular}


Dansieh, S.A./Proverbs and naturalness in mother-tongue translation

\begin{tabular}{|c|c|c|c|c|c|}
\hline 38. & $\begin{array}{l}\text { James } \\
3: 11,12 \\
\text { Does a } \\
\text { fountain } \\
\text { send forth } \\
\text { at the same } \\
\text { place sweet } \\
\text { water and } \\
\text { bitter...Can } \\
\text { a fig tree } \\
\text { bear olive } \\
\text { beries? }\end{array}$ & 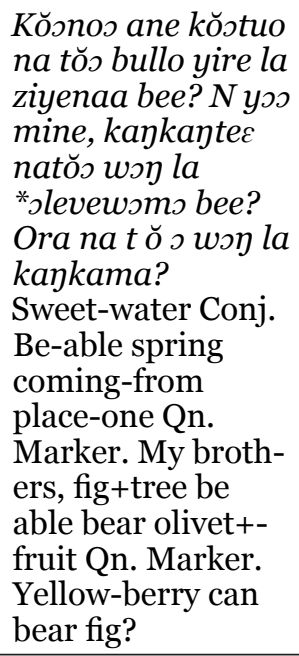 & & $\mathrm{X}$ & \\
\hline 39. & $\begin{array}{l}2 \text { Peter } \\
2: 22 a \\
\text { Wallowing } \\
\text { in the mire. }\end{array}$ & $\begin{array}{l}\text { Bille memere pos } \\
\text { Roll-over+Prog. } \\
\text { Mud inside. }\end{array}$ & $\mathrm{X}$ & & \\
\hline 40. & $\begin{array}{l}2 \text { Jn } 1: 11 \\
\text { God speed }\end{array}$ & $\begin{array}{l}\text { Tuori } \\
\text { Meet }\end{array}$ & & & $X$ \\
\hline 41. & $\begin{array}{l}\text { Rev 3:16a } \\
\text { Lukewarm }\end{array}$ & $\begin{array}{l}\text { Ba waa maaroy } \\
\text { bee toloy } \\
\text { Neg. be cold Conj. } \\
\text { hot }\end{array}$ & $\mathrm{X}$ & & \\
\hline 42. & $\begin{array}{l}\text { Rev. 3:16b } \\
\text { Spew out }\end{array}$ & $\begin{array}{l}\text { Poore bare } \\
\text { Spew throw-away }\end{array}$ & $\mathrm{X}$ & & \\
\hline
\end{tabular}




\section{Discussion}

The study considered which of the translated proverbs and/or idioms were natural; those that were near natural and those that were deemed less natural. This was done with a view to revealing why the natural ones are said to be so, and why those deemed to be less natural tend to be so. English proverbs considered alien to Dagaare were also identified for suggestions to be made on how best they could have been translated into the RL.

From Table 2, the results obtained were: Natural $=14$; Near Natural $=$ 21; Less Natural $=7$. This implies that most (50\%) of the proverbs translated into Dagaare were deemed near natural. Those that were considered natural by respondents constituted $33 \%$, while those that were deemed less natural represented $17 \%$.

The study observed that proverbs that had almost word-for-word equivalents or expressed familiar concepts in Dagaare were those considered by respondents as natural. Classic examples included Sample Proverbs 3, 10, 11 in Table 2 (from Matthew 27: 24; 2 Peter 2: 22; Matthew 15: 13; 21:42; Mark 2:21; Rev 3:16a and16b). For instance, the concept of dogs eating their own vomit in 2 Peter 2: 22, is not new to the Dagaaba. In fact, there is a similar proverb in the language for expressing the idea of individualism which is gradually creeping into Dagaare culture - a culture that is known for its high communal spirit. It is not uncommon to hear the people say:

Pampana baa ba la dire o to tiiri.

Now dog Neg. Rep.-Marker eat $3^{\text {rd }}$-Pers-Sing-Pron.kind vomit.

Literal meaning: These days, dogs no longer eat the vomit of their kind.

Metaphorical meaning: These days, no one cares for someone else's child.

Even though the underlying meaning of this proverb in Dagaare is not exactly the same as the example from 2 Peter 2: 22, one fact is affirmed: Dogs do return to their vomit. "Casting the first stone" from John 8:7: Though not a proverb that exists in the language, the idea it expresses in the SL is so clear that neither the translators nor the readers found any difficulties in understanding it. Similarly, "wallowing in the mire" from 2 Peter 2: 22 is a familiar concept, as most of the Dagaaba rear pigs and are very aware of those animals' fondness of wallowing in the mud. The expressions "lukewarm" and "spew out" used in Revelations 3:16a\&b provide interesting connotations: The word "lukewarm" has an exact equivalent in Dagaare - polspols; however, the translators opted for a descriptive phrase 
that included the adjectives "cold" (maarop) and "hot" (tolop) which are often used to describe slow or sluggish and active persons respectively. The reduplicant polopslo, though the exact equivalent of lukewarm is used exclusively for liquid and not persons, not even in the metaphorical sense. "Spew out" rendered by the translators as Poore bare in Revelations 3:16b is another familiar concept in Dagaare. Nonetheless, it has further connotative extensions that should be clarified to avoid confusion in the minds of the reader: The expression poore/toore bare (to spew out) in Dagaare can also be used in contexts where a person who has uttered a curse is rebuked and asked to retract the curse.

The 21 proverbs that were considered by respondents as near natural were observed to sound more literal than proverbial in the receptor text. Five of them are discussed here, namely: Mt. 5:41 "to go the extra mile"; Mt. 5:38 "an eye for an eye and tooth for a tooth"; Mt. 7:6 "to cast pearls before swine"; Eph. 6:12 "in the twinkling of an eye" and I Corinthians 15:33 "bad company ruins good morals". There was the likelihood that the translators leaned more towards the source text meaning than they did towards the production of a natural translation into the receptor text that represented the source text proverbs with equivalents or near equivalents in the Dagaare text. It was also observed that the use of proverbs in a translation could depend on the translator's own mastery of their use in everyday language. The respondents could understand what was implied by those statements, albeit with a bit of explanation. The translation of Matthew 12:25 in particular, presented an interesting observation: Even though the idea expressed here of a divided house not being able to stand is clear, the Dagaaba have a similar proverb that could fit in this context more naturally:

Dankyinin may were ka nanne zo kpe te pa

Wall-Spec. Hab. crack that scorpion+Pl. run enter go fill-in

Literal: When a wall cracks, it makes room for scorpions to creep in

Metaphorical meaning: A house divided against itself cannot stand.

The proverbs in Galatians 5:4 "to fall from grace"; I Cor. 9:9 "to muzzle the ox that treads the grain"; Matthew 10:6 "Signs of the time" whose renderings in the Dagaare texts were considered less natural by respondents, tended to be the most literal of all the translated proverbs in Dagaare. The Dagaaba have expressions that are near equivalents of these 
sayings that could have been used. For instance, "Signs of the time" could be rendered as "nyalaanyiili". Falling from grace, usually expressed as

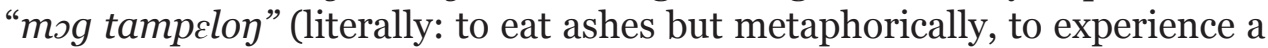
reversal of fortunes) or "nye woore" could also fit in the latter.

\section{Conclusion}

This study investigated the extent of naturalness in the translation of English proverbs into Dagaare, using the Dagaare New Testament: Naaymen Nspaalaa Gane. Using the scale of natural - near natural - less natural, it was observed that majority (50\%) of the proverbs translated into Dagaare was near natural. Those that were deemed natural constituted $33 \%$; while those that were considered less natural represented $17 \%$. The extent of naturalness in the translated texts depended largely on the level of literalness in the translation. The study argued that the profuseness in the use of proverbs in a translation could depend on the translator's own mastery of their use in everyday language. How well a translator knows, understands and uses proverbs in daily discourse could greatly determine how frequently and appropriately they use proverbs in a translated text. Yankah's (1982) article: "The Proverb and the Western Educated: Use or Neglect" is considered particularly interesting for this study. Though the people who translated the NT into Dagaare might not have been trained in the West, the formal education received locally in Ghana is modelled upon that of the West. It would be interesting to find out whether their use or misuse of proverbs could be linked to their educational background. This present study cannot claim to be exhaustive in its discussion of issues relating to proverbs and naturalness as it only examined the subject as it pertains to Dagaare and the English language, both of which are, strictly speaking, receptor languages. Therefore future research could look at the level of naturalness of translated proverbs not just from the English language, but also from the Greek and Hebrew languages. 


\section{References}

Anderson, D. (1998). Perceived Authenticity: The Fourth Criterion of Good Translation. Notes on Translation 12(3): 1-3.

Barnwell, K. (1992). Manual for Bible Translation: Introductory Course on Translation Principles. Dallas: Summer Institute of Linguistics.

Chemorion, D. C. (2009). Considerations for Acceptability in Bible Translation. Verbum etEcclesia 30(2) Art. \#343, 5 pages. DOI: 10.4102/ve.v30i2.343

Dressler, W. U. (2003). Naturalness and Morphological Change. Berlin: De Gruyter.

Crossway Bibles (2001). English Standard Version. Wheaton, IL: Crossway. Fadaee, E. (2011). Translation Naturalness in Literary Works: English to Persian. International Journal of English and Literature. 2(9): 200205. Available at: www.academicjournals.org/ijel DOI: 10.5897/ IJEL11.089.

Hashemi, H. (2009). Naturalness in Translation. Art of Translation and Interpreting. Available at: www.proz.com Accessed on: $19^{\text {th }}$ October, 2017.

Larson, M. L. (2201). Meaning-based Translation. New York: University Press of America.

Mbiti, J. S. (1995). The Gospel and African Culture: Use and Unuse of Proverbs in African Theology. Paper Presented at a Consultation on African Proverbs and Christian Mission in Maputo. 27-31 March, 1995.

Bibles International (2015).Naaymen Nolay Paalaa. Grand Rapids, Michigan: Bibles International.

Bible Society of Ghana (2014).NaaymenNspaalaaGane. Accra: Bible Society of Ghana.

Churches of Christ (1999).New Revised Standard Version. USA: Division of Christian Education.

Nida, E. A. (1943). Towards a Science of Translation, with Special Reference to Principles and Involved in Bible Translating. Leiden, the Netherlands: E.J. Brills for the United Bible.

Ojoade, J.O. (1983). African Sexual Proverbs: Some Yoruba Examples. Folklore 194(2): 201-13.

Rahimi, R. (2004). Alpha, Beta and Gamma in Translation: Towards the Objectivity of Testing Translation. Translation Studies 2(5). 
Dansieh, S.A./Legon Journal of the Humanities Vol. 30.1 (2019)

Schiemann, J. (2011). Naturalness and artificiality in Bioethics. Human Nature and Self-Design. Paderborn: mentis Verlag GmbH.

Van Heerden, W. (2013). The Proverb is the Drum of God: On the Use of African Proverbs in the Interaction Between African Culture and the Christian Faith. Scriptura 81 (2002): 462-475.

Yankah, K. (1982). The Proverb and the Western Educated: Use or Neglect. Available at: www.scholarworks.iu.edu Accessed on $21^{\text {st }}$ October, 2017. 